\title{
Institutions and Intellectuals That Configure the Concept of the Environment and Development in Latin America and Its Global Impact*
}

\author{
Fernando Estenssoro, Eduardo Déves
}

Advanced Studies Institute of Universidad de Santiago de Chile, Santiago, Chile.

Email: fernando.estenssoro@usach.cl, eduardo.deves@usach.cl

Received July $1^{\text {st }}$, 2013; revised August $4^{\text {th }}, 2013$; accepted August 29 ${ }^{\text {th }}, 2013$

Copyright (c) 2013 Fernando Estenssoro, Eduardo Déves. This is an open access article distributed under the Creative Commons Attribution License, which permits unrestricted use, distribution, and reproduction in any medium, provided the original work is properly cited.

\begin{abstract}
This paper is part of a research into the Latin American thinking on international affairs and a continuation of a line of work on Latin American contributions to the environmental discussion installed in the global political agenda in the early 70s. The premise was that Latin American contributions were initially made by professionals closely related to ECLAC, UNEP and the Bariloche Foundation. These professionals and agencies understood how poverty and backwardness were endured by the majority of the regional and world's population was one of the main causes of environmental degradation; consequently, overcoming the environmental crisis meant that underdevelopment should be eradicated without delay. This view of the environmental problems was synthesized in the combined concept of "environment and development", which was also understood in the region as "eco development". Finally, the broad phenomenon they wanted to describe using the terms "environment and development" was summarized in the concept of sustainable development as defined in the 1987 World Commission on Environment and Development report "Our Common Future".
\end{abstract}

Keywords: Environment and Development; Environmental Crisis; Latin American Intellectuals; World Politics

\section{Introduction}

The hypothesis that the 70's and the first part of the following decade were key years in Latin America (LA) was worked on in this article for building and later socializing environmental concerns from a perspective that linked the environment protection issue with the unavoidable needs of the region's development. This process was the work of a first group of Latin Americans related to the Economic Commission for Latin America and the Caribbean ECLAC (CEPAL, as per its acronym in Spanish), to the Latin American Office of the United Nations Program for the Environment (UNEP, as per its acronym in Spanish) and the Bariloche Foundation. Both the persons and institutions stated were embedded, for several years, in the worldwide discussion existing in relation to topics pertaining to development and subdevelopment. Therefore, they picked up the environ-

\footnotetext{
* This article is the result of research Fondecyt No 1110860: Towards a mapping of the International Latin American Thinking of the Twentieth Century: works, problems, schools and categories.
}

mental issue and related it to the subject of development, seeking to educate and socialize in this perspective the political, intellectual elite, and LA decision makers when facing the environmental problem.

Moved in principle by the call of the United Nations (UN) to hold the Conference on Human Environment in Stockholm in June 1972, they formed an intellectual framework demonstrating and expressing their thoughts, mainly, through the preparation and exposure of different encounters, from regional interests and perspectives, but, additionally with the clear purpose of influencing and focusing the development policies of the region's governments [1].

Based on what was contributed by center-periphery theory and dependence on the 50's and 60's, they included in their reflections the increasing transnationalization and interdependence phenomenon of the world economy along with the complex and nascent variable of worldwide environmental crisis, affecting practically all areas of social activities that was placed in the world agenda by the UN in Stockholm in 1972. 
Thus, with contribution of these intellectuals, a new eidetic and conceptual corpus was formed that defined the new challenge of caring and preserving the environment along with the most traditional, taking care of issues pertaining to development and sub-development. This merger of issues that initially emerged separately and conflicting would be expressed in a compound concept that was socialized as environment and development. This compound concept that turned into the fighting banner of the Latin American perspective and the world undergoing development in general, was finally fully adopted in the sustainable development concept, as was defined by the World Commission on Environment and Development (CMMD, as per its acronym in Spanish for Comisión Mundial de Medio Ambiente y Desarrollo), in its re-known 1987 report Our Common Future.

The main ideas of this corpus are given through the speech of some of these intellectuals, representative of the aforementioned centers.

\section{Contribution of Intellectuals Related to the Economic Commission for Latin America and the Caribbean (ECLAC)}

Although it is true that the first time that the issue of the environment and development were related from the Third World perspective, or rather, in understanding that the greatest variable that the worldwide environmental crisis generated was poverty and under development and, therefore, the most urgent activity to overcome this environmental crisis was precisely to overcome the under development conditions in which most of humanity was living, was the Founex Meeting in 1971, ECLAC immediately picked up this interpretation and transformed it into the strength idea that would focus, until today, the perspective to understand the environmental issue in these countries [2].

The first ideas that ECLAC reflected regarding the matter were in 1971, upon petition of Maurice Strong himself, Secretary General of the 1972 Stockholm Conference, who requested that ECLAC determine the environmental problems of the LA.-Caribbean Region "that would require a priority attention and to draft an action plan to attack them" [1]. In order to do so, ECLAC, supported by ILPES, called the "Regional Latin American Seminar on Human Environmental Problems" event that is considered as one of ECLAC's "initial approaches to the environmental issue" [3]. A study was presented for discussion in this seminar called "Human Environment and Development in LA", where, just as in the Founex Report, it was stated that the environmental crisis had been generated by developed countries and although it could be a worldwide phenomenon, the problem was that the rich and industrialized countries only underscored aspects derived from their own high industrialization and opulence, however, in LA the contrary was happening, given that the environmental crisis was due to its nature of being an underdeveloped region, in addition to being a bio-geographical zone different from the First World, which is why a solution must be designed to the environmental issue from its own perspective:

The concentration of the economic activity and growth in urban centers has contributed to deteriorate the environment surrounding mankind in highly industrialized countries to such extent that their governments have been forced to establish the need of adopting radical measures (...) In Latin America bad environmental conditions were mainly originated in their scarce economic development level, accompanied by deficient income distribution and social structures that tend to make this situation permanent. When the industrialization process was produced in the region, necessary to overcome the under development status and starting to use modern technologies, new environmental problems were added to the traditional ones, making the already deteriorated situation in rural and urban environments more serious (...) Under development modifies and conditions that way that environmental problems are taken on in Latin America and these, in turn, are added to other aspects that are characteristic of under development. There is no other alternative than continuing to give top priority to development plans and policies, but enriching them with new elements provided by the study of environmental problems, already important in many countries and that will acquire future increasing significance [4].

This line of thought continued immediately after the conclusion of the Stockholm Conference in March 1973, creating a joint unit ECLAC/UNEP in charge of coordinating activities related to the environment and where the "analysis of environmental problem features in LA and its relations with development" would be privileged [5]. Thus, between October 21 and November 29, 1974 the "First Latin American Planning Course of Development and the Environment" was held in Buenos Aires with the participation of " 14 Argentinean grantees and 12 from 10 South American countries", in addition to "20 professors" [6]. In addition, the ECLAC-UNEP Project was coordinated between 1974-1976, with the objective of drafting an inventory of regional environmental problems that would focus the region's governments and agencies [1].

\subsection{Sunkel-Gligo: Development and Environment Styles in Latin America}

However, perhaps the ECLAC-UNEP Project that influenced most of the socialization of this perspective to un- 
derstand the environmental issue was the so-called Development and Environment Styles in LA, which was started mid-1978 and concluded mid-1980. Both Vicente Sánchez, then in charge of the UNEP Latin American Office, as well as Enrique V. Iglesias, ECLAC's Executive Secretary, were seeking with this project to impact in the political-executive authorities of the region that showed little knowledge regarding the environmental value in development issues [7]. In order to do so, they offered project management to Osvaldo Sunkel, at that time living in England, under the conviction that their prestige would allow permeating through this resistance that was shown both by specialists in economy and development issues as well as political and executive authorities [7]. Of course, Sunkel conscious of the fact that they did not have any greater specialization in the environmental issue, established the condition that a team of experts in the matter should be contracted. Given the above, when he arrived to Chile and contacted Luciano Tomassini, who was then Enrique Iglesias' advisor at ECLAC, he immediately introduced him to Nicolo Gligo, agronomist and ecologist that during the Salvador Allende's presidential administration (1970-73) had directed the Chilean Institute of Natural Resources of Chile (IREN its acronym in Spanish). Regarding the intellecttual contribution made by Gligo to Sunkel's thinking he recalls: "I could discover with him what I consider the key to understanding the field of study of ecology, the notion of ecosystem, the comprehension that we are all part of one single ecosystem and that there is a direct relationship between what's going on in the society and nature (in its widest sense). This was a very rich reflection as I realized not only that there is a nature, but also that there is a transformed nature, a natural environment and an artificial manmade environment and that everything is interconnected. Similarly, the international economic trends, either in the rural and urban development have strong implications from the environmental standpoint” [8]. Thus, Gligo and Sunkel formed a highly complementary team that became a key element for the project's success, among which main activities were holding the inter-disciplinary seminar "Development and Environmental Styles in LA", held between November 19 and 23, 1979, in Santiago, Chile and that gathered more than 500 professionals and personalities of the region and, additionally, allowed the new publication with the same name in 1981, which became a classic work of the issue in FTA [9]. In this endeavour they were certainly assisted by a large number of experts with whom they teamed up at the ECLAC. One of them was Gilberto Gallopin who, according to Gligo, was a key contributor as an expert systems analyst and ecologist who "helped us to define the environment as the mediation of the environment by the society, not anymore as something related only to natural resources as it was understood back then. It opened the way for us to put a stress on the social and political aspects of the environmental issues, along with the natural side" [10].

It is considered that this Project and the later publication of Estilos de desarrollo y Medio Ambiente en la $A L$ (Development and Environmental Styles in Latin America), was the critical boost to socialize the perspective stated of the environmental issue in the region. E.g., Ignacy Sachs, questioned in 1983 regarding the need to progress in sustainable development processes in LA, stated that "the starting point is already present, provided through the seminars organized in 1979 by ECLAC and other regional commissions of the United Nations in collaboration with UNEP, in terms of development styles and alternative models on the use of resources" [11]. Similarly, the Colombian Margarita Marino de Botero, from the Institute of Natural Resources of Colombia (INDERENA, Instituto de Recursos Naturales de Colombia), underscored the importance of this project on asserting that, in order to deal with this region's environmental problem, the "most important contribution seems to be considering the development styles such as the fundamental framework of the discussion regarding the environment, economic and technological future and social progress of LA" [12].

The truth is that in the different articles published in this work, it is made explicit how the environmental variable was inserted in the ECLAC structuralist tradition, initiated with the center-periphery and dependency theory, making it evolve to the phenomena relative to the transnationalization and economic interdependence that Sunkel was already studying during the first half of the 70 's, and that were modifying the international order in a process that, in the following decades was going to be made popular as globalization.

\subsection{Raúl Prebisch: The Environmental Crisis Was Generated by the Irrational Capitalist Development Model of the Center}

Prebisch made explicit that it was capitalism and his hegemonic development model, as well as the dominant center-periphery dominant power relations, which had caused the environmental crisis and, particularly, after the end of the Second World War, the greatest responsebility lied in the United States as the main world capitalism center:

It is possible to see this more clearly than before in the capitalist development of the centers. The extraordinary momentum of the last decades to recent times is not only the result of an impressive technical progress but also 
from the irrational exploitation of natural resources, particularly energy resources that, in turn, has noticeably influenced the technical focus. There has been, therefore, a false element in the system functioning of very dramatic world consequences. In all of the aforementioned, the hegemonic power of the centers in the periphery of world economy has been of decisive importance, particularly that of the United States, the main dynamic capitalist center [13].

Therefore, if the planet's ecosystems were threatened it was the result of capitalism's irrational development, which had led to "the depredation of non-renewable natural resources, particularly those of energy resources and the phenomena of contaminating air, rivers and seas, as well as the deterioration of natural resources that, despite their renewable nature, are not exempt from the adverse effect of technical resources". These were very flagrant phenomena, to which "the possible and very serious effects on climate of the growing emission of carbon dioxide into the atmosphere" must be added [13]. In addition, all this environmental destruction had also reached the periphery that "on pursuing the arcane design of developing in the image and likeness of the centers", also reproduced its evils, since it seems "evident that the imitation of the consumption forms of the latter had to bring with it the irresponsible use of natural resources". However, despite this, it should not be forgotten that in all cases in the periphery this destruction happens "with much less intensity than the one in the centers". Although, on the other hand, the growing urban concentration occurring in the periphery shows "very acute contamination phenomena comparable to those of the center" [13].

On the other hand, Presbich stated that this environmental problem, as such, expressed in LA and in the Caribbean was not new, but that they came from way back, only that now it had turned very serious, global and complex. The complexity itself of the problem stated that now the centers cannot "become isolated with a sanitary cord of the adverse events of the periphery. For the first time they are referring to interdependence. Of course, it is interdependence among unequal ones, but in any case the adverse repercussion that happens in the periphery from the lack of action of the centers will react sooner or later over the centers themselves. Such is the current complexity of the world" [13].

\subsection{Sunkel and Tomassini: The Environmental Issue Will Become Strategic in the Center-Periphery Relations}

In the same manner, Osvaldo Sunkel and Luciano Tomassini argued that the center-periphery relations had become more complex after the turning point of the expansive cycle experienced by the industrialized econo- mies between the end of the Second World War and the 70's. Pivotal point exacerbated during this decade by the oil crisis that led central economies to a growing transnationalization process of their companies seeking costs, factors of production and hand labor that are each time cheaper, but also less saturated and less destroyed systems by the then called negative externalities of the economic production process, such as the contamination of its industrial processes. Therefore, LA had to take on this new situation that characterized international relations and, among other measures, understand that their ecosystems were transformed into an economic resource that could be abusively treated by the developed countries (e.g. the case of the forestry mass in reference to the natural source of $\mathrm{CO}_{2}$ when facing the climate change phenomenon). In this respect, the environmental issue not only has to do with the contamination and resource degradation issues, but that it also became a strategic aspect of the North-South relations, in the growing transnational and interdependent North-South relations, in a growing transnational and interdependent world that was emerging [14].

\subsection{Enrique V. Iglesias: The Challenge of the Region Is to Balance Intensive Exploitation of Its Natural Resources with the Care of the Environment}

In turn, Iglesias underscored the key contribution that ECLAC performed to teach the idea that "development and the environment go hand in hand, so that one is the indispensable support of the other" and, thus, it becomes a fundamental idea within the global environmental debate. Certainly, it was recognized that the environmental issue left clear that we were living in a world that was more interdependent, but the contribution was the one that underscored that it dealt with a marked interdependence due to a profound lack of equality, where a third of humanity, the developed or the First World, h ad conditions that allowed a dignified life and two thirds lacked these conditions. In this respect, ECLAC contributed to the awareness of the Third World countries in general and to Latin Americans in particular, which in their development process reproduced environmental problems similar to the ones caused by the First World, but that now, under the sign of the environmental crisis, had to conciliate "the development effort and the preservation of the environment" [15]. This is an issue that had to be present in this part of the world, rich in natural resources and depending on them for their economic growth. Without a doubt, the exploitation of nature was an unavoidable process of progress and human development, but, similarly, ecological care by means of rational exploitation, seemed key for the present and future interests 
of these countries.

In extract, for Iglesias, LA could not could not dispense from the extensive exploitation of its resources, in order to progress in an accelerated manner to overcoming the pressing problems of under development, but had to do so in an environmentally sustainable manner:

The countries of the region must be the only way of satisfying the progress needs and hopes of societies, is through an intensive and rational exploitation of natural resources (...) But they also know as well that in this process, both science as well as experience of others are valuable instruments in order to avoid, if possible, that unavoidable errors turn into unnecessary detriment for present and future generations. In the combination of both purposes-intensive use of nature with efforts to minimize ecological effects on the environment-lies on the conciliation between the objectives of development and the preservation of the environment. Both together will contribute to the quality of life of today's and tomorrow’s Latin American man [15].

\section{The Bariloche Foundation: Overcoming the Environmental Crisis Does Not Go through Ending Growth and Development, but Rather to Reconsider It Socially}

From the theoretical-political view the two great global models that were confronted in the decade of the 70's around the environmental problem were, on the one hand, the outlook of developed countries summarized in the Club of Rome Report, Los Límites del Crecimiento (Growth Limits) [16], and the outlook of countries undergoing development expressed in the Bariloche Group Report or Bariloche Foundation [17], "Catástrofe o Nueva Sociedad" (Catastrophe or New Society?) formed by LA specialists tied to development topics and the North-South relations [18].

This process of responding to the environmental crisis by means of generating an LA alternative and own model was started in 1970 due to the invitation that the Club of Rome along with the Institute of Technological Research of Rio de Janeiro, joined a group of scientists to discuss the central thesis that they have been working on, for the Club of Rome, Dr. Dennis Meadows and his team of the Massachusetts Institute of Technology (MIT), and that will be finally known as The Limits to Growth. In this meeting, that was held in Rio de Janeiro, the attending Latin Americans questioned the basic assumptions with which Meadows and its team had built its model, and, due to this, they entrusted the Bariloche Foundation to build its own model that picked up this critical approach. Thus, a first group was constituted formed by Carlos A. Mallmann, Jorge Sábato, Enrique Oteiza, Amilcar Her- rera, Helio Jaguaribe and Osvaldo Sunkel, who delivered, at the end of 1971, a first document with the hypothesis and variables to contest Meadows and its team. Afterwards, Amílcar Herrera was appointed as project head, who formed a work team with another 17 scientists who drafted the final version of the report [18]. This report was first published in 1976 in the journal Nueva Sociedad, under the title Modelo mundial latinoamericano (Latin American World Model) also known as the Bariloche Model [23]. The answer of the Bariloche Group, stated that the main problem in the world was not the physical limits of the planet that impeded an undefined growth, as well as the neo-Malthusian fears, as was proposed in the Roma Club report, but rather, the main problem was of a social political nature and lied in the unequal distribution of power and wealth in the world. Therefore, the solution consisted on making profound changes in the social dominant organization:

The ideal society project [that the Bariloche Model asserts] is born as a response to the opinion current, that particularly in developed countries assert that the fundamental problem faced by current humanity is the limit imposed by the physical environment. As is well-known, according to this conception, the exponential increase of consumption and the population will fatally finish exhausting the planet's natural resources, probably in the coming future. In addition, and despite the fact that natural resources are not exhausted in the foreseeable future, the growing contamination of the Environment will produce the collapse of the ecosystem on the short-term. The final result will always be the same: catastrophic detention of growth with the massive death of the population and the decreasing general life conditions at the pre-industrial levels (...) The attitude of the authors of this model is radically different: it sustains that the most important problems facing the modern world are not physical but rather social-political, and are based on the unequal distribution of power, both internationally as well as within countries, throughout the world [19].

Certainly, the Bariloche Model rejected the argumentsconsidering them deterministic-, of the "growing limits", which rejected the possibility of unlimited economic growth and that, following the development model of industrialized countries, all people living in the world would reach a level of development and quality of life similar to the one that characterized the First World countries. The deterioration of the physical media for Latin Americans was not "an unavoidable consequence of human progress, but the result of a social organization founded on values, mostly destructive", and in that respect, the human fate did not depend "on a last instance, on physical insurmountable barriers, but on social and political factors that it competes for mankind to modify” 
[20]. In that respect, the catastrophic perspective of the Club of Rome was contested by the Bariloche Group from a regulatory perspective, setting forth "rather a goal, i.e. a desirable future, that is defined and that what must be done to reach this desirable future, starting from today's situations and conditions" [21].

\section{The United Nations Environment Program (UNEP)}

The United Nations General Assembly established the UNEP on 15 December 1972, following the resolutions of the Stockholm Conference. The UNEP's Governing Council is made up of 58 member states with headquarters in Nairobi, Kenya [22]. This program would prove vital for Third World countries in their efforts to establish an indissoluble link between the Environment and Development. What is very interesting in this connection is that Vicente Sanchez, former plenipotentiary ambassador of Chile to the 1972 Stockholm Conference was one of the main architects of this endeavor on UNEP's side.

Sanchez said he continued to work on environmental issues immediately after the Stockholm Conference in his role as international staff member of the Chilean Mission to Geneva. The first meeting of the UNEP's Governing Council was held on June 1973. Sanchez was elected one of the two vice chairs of the UNEP in this meeting, besides leading the committee responsible for discussing the management of the US\$ 100 Million UNEP Fund. The urgency of establishing an Executive Secretariat to start working as soon as possible was also discussed during this first meeting. The UNEP opened its brandnew offices in Nairobi on 3 October 1973, with the presence of its chief officers, the Canadian born Executive-Director Maurice Strong, the Deputy Director Mostafa Tolba from Egypt, and UNEP's Fund Director Paul Berthoud from Switzerland. There was also a line of medium-ranking officers present at the opening, among which Vicente Sanchez who was in charge of the UNEP's Division of Economic and Social Programs PNUMA [7].

This division continued driving the link of the environment and development concepts that started two years ago at FOUNEX; an ideal Sanchez had embraced and vigorously advocated during the 1972 Stockholm Conference [7].

Later on, the Regional Office for Latin America and the Caribbean of the United Nations Environment Program was established in 1975, with Mr. Vicente Sanchez as its first Director, and a head office in Ciudad de Mexico. Sanchez played a crucial role there as articulator and witness to all initiatives focused on disseminating this view now summarized as environment and development in Latin America.

\section{The Concept of "Eco-Development" as Background to the Concept of Sustainable Development}

In this regard, it is important to clarify that in the 70s and early 80s the concept of Sustainable Development had not yet been defined, explained and widely disseminated as it was in the World Commission on Environment and Development (WCED) famous 1987 report "Our Common Future" [24]. "Eco-development", the term most commonly used back then, referred to the need to ally the care for the environment with development requirements as identified by the representatives of developing countries.

In other words, in the early years, the concept of "ecodevelopment" associated in one single term the idea that the development and care of the environment would go hand in hand, and that they were not clashing words at all. The concept was also used to oppose to the merely economistic approach to development (associating development to economic growth only), the mechanical imitation of the First-World pattern of economic growth, and also to support the idea that developing countries should find their own path to development. Maurice Strong was the first to use the concept of "eco-development" in this context when speaking at the first meeting of the UNEP's Governing Council in Geneva in June 1973, encouraged by the Founex Report, to depict the idea that "development and the environment are not in conflict with each other, yet they constitute two different aspects of the same concept. What is really at stake is the rational management of resources with the purpose of improving mankind's global habitat and ensuring a better quality of life for all human beings. Again, this concept of development is now expanding and becoming more accurate [25]. But Ignacy Sachs has been the author who intellectually elaborated on this concept to try and regain the spirit of the Founex Report, profoundly discussing this concept in his paper "Environment and Styles of Development" [26], and subsequently in the book "Stratégies de l'éco développement" (1980), and in many other articles in which he defined eco-development as a "socially desirable, economically viable, and ecologically prudent development” [27].

What's interesting about this concept, in this construction, is that it was immediately adopted by such outstanding personalities of the environmental discussion of those years as Vicente Sánchez, Héctor Sejenovich, Jaime Hurtubia, Francisco Szekely, and Enrique Iglesias, among others, who worked together back then at the UNEP and the ECLAC.

For instance, Sánchez and Sejenovich published in 
1978 the article: "Ecodesarrollo: Una estrategia para el desarrollo social y económico compatible con la conservación ambiental"; nine years before the "Our Common Future" Report which conceptualized the concept of sustainable development was published they wrote:

We consider eco-development as a model of economic development endorsing the use of resources to satisfy the needs of the current and future generations of population, by maximizing functional efficiency of eco-systems in the long run, employing technologies suited to that end, and by fully deploying the human potential within an institutional arrangement that allows people to participate in the fundamental decisions [28].

Both authors are also editors of the book "Antología en torno al ecodesarrollo" (Anthology Surrounding EcoDevelopment) published in 1983. The book describes again how, during the preparation of the 1972 Stockholm Conference on Human Environment and at the actual conference, the environmental issues arose as a global concern focusing in the relationship between the quality of the environment and development processes; developing countries, especially those of Latin America stressed from the very beginning of the conference on the relevance of achieving a comprehensive view of the environmental and development topics, discussing the need for "growth patterns and economic development suitable to the environment" and the search for development patterns involving environmentally friendly “ $\ldots$ alternative technological and social strategies for the use and consumption of natural resources...” [29].

Likewise, we should mention that the UNEP financed the publication in 1983 of the Colombian book "Ecodesarrollo, el pensamiento del decenio" (Eco development, the thought of the past decade), in which Enrique Iglesias wrote the article: "The Past, Present, and Future of EcoDevelopment" stating that "contrary to the trend to consider the ecologic issue negatively, as a cost that must be absorbed, it becomes clear today that there are forms of economic development that benefit openly from a suitable management of the environment" and in this respect, from ECLAC they have been adamant in saying to "governments of the Region that managing the environment is important not only for ecological preservation purposes, but also as a positive economic factor adding to many others [30].

\section{The World Commission on Environment and Development (WCED) and the Concept of Sustainable Development}

As a matter of fact, most of the viewpoints proposed at an earlier stage under this concept of "eco-development" were extensively recovered in the definition of the concept of "sustainable development" as defined in the 1987
WCED Report "Our Common Future".

The WCED was formally established on 19 December 1983 by the UN General Assembly at its $38^{\text {th }}$ session as a special commission that would put forward long term environmental strategies for a sustainable development, even if it adopted its current name of World Commission on Environment and Development in 1984. In order to support the work of the Commission the World Research Institute (WRI) invited in May 1984 to an international gathering to be held in Washington, D.C. under the theme "The Global Possible: Resources, Development and New Century". The purpose of this conference was to have a group of 75 world leaders of science, governments, the industry and the civil society organizations respond to a question they considered essential: Can the world today reverse the current environmental degradation and promote a better quality of life for all at the same time, achieving significant improvements of living standards of the destitute? [31].

Certainly, Maurice Strong and Gro Harlem Brundtland were among the guests, but also was Vicente Sánchez, now in his capacity as Director of the Mexican "Instituto de Medio Ambiente y Desarrollo del Colegio de México" (Institute of the Environment and Development of the Mexican School) (Ibíd.). In this meeting Ms. Brundtland asked Mr. Sánchez to take up the Executive Secretariat of the WCED [7].

So, once more Mr. Sánchez became a witness and a privileged player in the North-South discussion on how to deal with the environmental issues. It took an intense period of discussions and negotiations in the Commission that stretched for almost 4 years, to reach a common position between developed and developing countries on how to comprehend and consequently, solve the environmental crisis. The final consensual formula is synthesized in the famous concept of Sustainable Development discussed extensively in the Commission's report:

Sustainable development is development that meets the needs of the present without compromising the ability of future generations to meet their own needs.

It contains within it two key concepts:

the concept of "needs", in particular, the essential needs of the world's poor, to which overriding priority should be given; and the idea of limitations imposed by the state of technology and social organization on the environment's ability to meet present and future needs. (...)At a minimum, sustainable development must not endanger the natural systems that support life on Earth: the atmosphere, the waters, the soils, and the living beings... [24].

Finally, in 1987 the General Assembly at its Plenary Session of December 11 commended the WCED's work and endorsed the concept of sustainable development as 
defined in the Report. The General Assembly also borne in mind that, on the nature of issues of environmental degradation and measures to redress it, the world's governments shared the criteria that underdevelopment was one of the major issues since "... generalized poverty is usually one of the major causes of environmental degradation, the eradication of poverty and equal access of all individuals to resources are essential to achieving sustainable improvements of the environment [32].

As a result, 19 years after the UN summoning of the Conference on Human Environment, the international community represented at the UN General Assembly was able to reach an agreement to move forward on the resolution to environmental issues by linking definitively the concepts of Environment and Development in one single indivisible phenomenon summarized in the formula of Sustainable Development. In other words, the environment and development, the central outlook developed by Latin American intellectuals to be able to comprehend the global environmental crisis had been formally accepted by the United Nations. This would subsequently open the path for the General Assembly resolution at its Plenary Session on 22 December 1989 inviting to a new summit to be held in Rio de Janeiro, Brazil in 1992. This time the name would be "United Nations Conference on Environment and Development" calling to re-launching the environment theme as one of the most relevant topics of the world's political agenda [33].

\section{Conclusions}

1) We got conclusion by asserting that in Latin America the link between development and environment had been embraced at a very early stage essentially thanks to the activity of intellectuals associated with the ECLAC, the UNEP and the Bariloche Foundation as a powerful idea that would guide its approach to the topic of the environment protection embedded in the global public agenda on the occasion of the celebration of the 1972 Stockholm Conference on Human Environment;

2) Latin America played a relevant role in shaping this idea which emerged from the discussions held in 1971 at the Swiss locality of Founex and gained momentum in the following years to become hegemonic in the global environmental discourse, and in the materialization and enrichment of this complex concept of "environment and development";

3) In this connection, the existence of the ECLAC with all the contribution made to the global thinking, with the "dependency" and "underdevelopment" theories and its role linking a significant number of intellectuals and professionals from the region and the world to reflect on the problems of world policy from the regional perspective made it easier for Latin American authors to link concepts on environment and development at a very early stage in the context of ECLAC's eidetic trajectory, imprinting a Latin American hallmark into this concept.

4) This process has been expanded and supported resolutely from the very beginning by the UNEP, reinforced by the installation of the UNEP's regional office in Ciudad de Mexico and close collaboration with the ECLAC. Also the activity deployed by Bariloche Foundation has been important, whose members interacted either with the ECLAC or the UNEP. According to Margarita Marino de Botero, the seminar organized by these agencies in 1979 on styles of development and environment, and the response to the thesis on Limits to Growth by the Bariloche Foundation who proposed "growth conditions in agreement with the available resources and technologies" were crucial to "consider styles of development as the fundamental framework of discussion on the environment, the economic and technological future and social advancement in Latin America” [12].

5) Scholar minds and wills were interconnected in Latin America through the intellectual networking of members of these agencies acting in the international policy arena, and reacting against an approach to environmental issues by developed countries they considered narrow, unfair and partial. The final outcome had been the making of a complete regional eidetic body of thought that enhanced the world discussion on the environment.

\section{REFERENCES}

[1] J. Lizarraga and J. Hurtubia, "Los Asuntos Ambientales de América Latina y el Caribe en el decenio 1972-1982," Diez años Después de Estocolmo, CIFCA, Madrid, 1983, pp. 137-176.

[2] "El Informe de Founex", In: M. Marino de Botero and J. Tokatlian, Eds., Ecodesarrollo. El Pensamiento del Decenio, INDERENA/UNEP, Bogotá, 1983, pp. 51- 85.

[3] M. Tavares, "Economía Verde en AL: Los Orígenes del Debate en Los Trabajos de la CEPAL," Política Ambiental, No. 8, June 2011, pp. 69-81.

[4] Economic Commission for Latin America and the Caribbean, "El Medio Ambiente Humano y el Desarrollo Económico en América Latina,” ECLAC, México City, 1971, pp. 1-2.

[5] ECLAC Document, E/5275, 1973, p. 181. http://daccess-dds-ny.un.org/doc/UNDOC/LTD/S73/000/ 01/PDF/S7300001.pdf

[6] ECLAC Document, E/Cepal/989, 1975, p. 36. http://daccess-dds-ny.un.org/doc/UNDOC/LTD/S75/000/ 01/PDF/S7500001.pdf

[7] V. Sánchez, Interviewed by Fernando Estenssoro, Santiago, June, 2011.

[8] O. Sunkel, Interviewed by Fernando Estenssoro, Santiago, July 2011.

[9] O. Sunkel and N. Gligo, "Estilos de Desarrollo y Medio 
Ambiente en AL,” Fondo de Cultura Económica, México D.F., 1980.

[10] N. Gligo, Interviewed by Fernando Estenssoro, Santiago, June 2011.

[11] I. Sachs, "Estrategias de Desarrollo con Requerimientos Energéticos Moderados. Problemas y Enfoques,” In: M. Marino de Botero and J. Tokatlian, Eds., Ecodesarrollo. El pensamiento del Decenio, IDERENA/UNEP, Bogotá, 1983, pp. 318-328.

[12] M. Marino de Botero, "Introducción,” In: M. Marino de Botero and J. Tokatlian, Eds., Ecodesarrollo, El Pensamiento del Decenio, IDERENA/UNEP, Bogotá, 1983, pp. 16-17.

[13] R. Prebisch, "Biosfera y Desarrollo," In: Estilos de Desarrollo y Medio Ambiente en AL, O. Sunkel and N. Gligo, Eds., Estilos de Desarrollo y Medio Ambiente en AL, Fondo de Cultura Económica, México D.F., 1980, pp. 6790.

[14] O. Sunkel and L. Tomassini, "Los Factores Ambientales y el Cambio en las Relaciones Internacionales de los Países en Desarrollo,” In: Estilos de desarrollo y Medio Ambiente en AL, O. Sunkel and N. Gligo, Eds., Estilos de Desarrollo y Medio Ambiente en $A L$, Fondo de Cultura Económica, México D.F., 1980, pp. 288-317.

[15] E. V. Iglesias, "La Conferencia de Estocolmo 10 Años Después. Algunas Reflexiones,” Diez años después de Estocolmo, CIFCA, Madrid, 1983, p. 112.

[16] D. Meadows, et al., "The Limits to Growth. A Report for the Club of Rome's Project on the Predicament of Mankind,” Universe Books, New York, 1972, pp. 23-24.

[17] http://www.fundacionbariloche.org.ar

[18] A. O. Herrera, et al., "Catástrofe o Nueva Sociedad," Modelo Mundial Latinoamericano, CIID, Bogotá, 1977.

[19] A. O. Herrera, et al., "Catástrofe o Nueva Sociedad. Modelo Mundial Latinoamericano,” CIID, Bogotá, 1977, pp. 11-12.

[20] A. O. Herrera, et al., "Catástrofe o Nueva Sociedad. Modelo Mundial Latinoamericano,” CIID, Bogotá, 1977, pp. 13-14.

[21] V. Sánchez, "La Situación Ambiental Diez Años Después de Estocolmo,” In: M. Marino de Botero and J. Tokatlian,
Eds., Ecodesarrollo, El Pensamiento Del Decenio, IDE RENA/UNEP, Bogotá, 1983, p. 564.

[22] UN General Assembly Documents, A/RES/2997(XXVII), 1973.

[23] A. Herrera, “Modelo Mundial Latinoamericano,” Nueva Sociedad, No. 22, 1972, pp. 16-29.

[24] CMMD, “Nuestro Futuro Común,” Madrid, 1992. http://daccess-ddsny.un.org/doc/RESOLUTION/GEN/NR 0/274/68/IMG/NR027468.pdf?OpenElement

[25] H. Herzer, J. Sujoy, N. Prudkin and L. Helguera, "La Relación Entre El Hombre y Los Recursos Naturales. Algunas Consideraciones Teóricas Acerca del Medio Ambiente en AL,” Nueva Sociedad, Vol. 31-32, 1977, pp. 206-220.

[26] I. Sachs, “Ambiente y Estilo de Desarrollo,” Comercio Exterior XXIV, 1974, pp. 360-368.

[27] I. Sachs, "Ecodesarrollo: Concepto, Aplicación, Beneficios y Riesgo,” Agricultura y Sociedad, Vol. 18, 1981, p. 9.

[28] V. Sánchez and H. Sejenovich, "Ecodesarrollo: Una Estrategia Para el Desarrollo Social y Económico Compatible con la Conservación Ambiental,” Revista Interamericana de Planificación, No. 47-48, 1978, p. 152.

[29] V. Sánchez, J. Hurtubia, H. Sejenovich and F. Szekely, "Hacia Una Conceptualización de Ecodesarrollo,” In: V. Sánchez and H. Sejenovich, Eds., Antología en Torno al Ecodesarollo, San José de Costa Rica, Universidad Estatal a Distancia, 1983, p. 17.

[30] E. V. Iglesias, "Pasado, Presente y Futuro Del Ecodesarrollo,” In: M. Marino de Botero and J. Tokatlian, Eds., Ecodesarrollo, El Pensamiento del Decenio, IDERENA/ UNEP, Bogotá, 1983, p. 510.

[31] WRI, “The Global Possible Resources, Development, and the New Century,” WRI, Washington DC, 1984.

[32] UN General Assembly Documents, A/RES/42/186, 1987. http://daccess-dds-y.un.org/doc/RESOLUTION/GEN/NR 0/521/05/IMG/NR052105.pdf

[33] UN General Assembly Documents, A/RES/44/228, 1989. http://daccess-dds-y.un.org/doc/RESOLUTION/GEN/NR 0/557/10/IMG/NR055710.pdf? OpenElement 